\title{
MANAJEMEN FINANSIAL LEMBAGA PENDIDIKAN ISLAM \\ (STUDI TENTANG OPTIMALISASI ANGGARAN PEMBIAYAAN)
}

\author{
Nelly
}

\author{
Sekolah Tinggi Agama Islam Al-Ikhlas Sidikalang Dairi \\ Jl. Mesjid Sidikalang Dairi, Kabupaten Dairi, Sumatera Utara \\ e-mail: nelly.syahminin83@gmail.com
}

\begin{abstract}
Abstrak: Anggaran pendidikan kerap menjadi masalah dalam peningkatan mutu pendidikan, minimnya anggaran pemerintah menjadi kendala utama, dengan kondisi anggaran yang sedkit tentu diperlukan optimalisasi pembiayaan. Tujuan penelitian ini untuk menganalisis konsep dasar manajemen finansial lembaga pendidikan dan optimalisasi anggaran pembiayaan. Penelitian ini menggunakan metode penelitian kualitatif berbasis studi pustaka. Pengumpulan data menggunakan studi dokumentasi, yakni mengeksplorasi teori atau pemikiran bersumber ragam referensi. Analisis data menggunakan analisis konten, dengan cara menganalisis dan memberikan interpretasi data untuk menarik simpulan. Hasil penelitian menjelaskan bahwa. Sumber dana di peroleh sekolah berasal dari pemerintah berupa dana bantuan operasional Sekola, iuran uang sekolah siswa, dan bantuan donatur, instansi, sponsor dan infak atau sedekah. Dana yang ada kemudian disusun dalam rencana belanja Sekolah yang disusun oleh tim untuk kemudian disahkan oleh kepala sekolah dan komite sekolah. Pelaksanaan anggaran keuangan sekolah digunakan sesuai dengan rencana yang telah dianggarkan dengan efektif dan efisien, amanah, dan bertanggungjawab. Pertanggungjawaban keuangan sekolah dilaporkan pemerintah dan komite, dengan model akuntabel, dan transparan. Wujud optimalisasi dapat diwujudkan dengan penentuan skala prioritas saat penyusunan anggaran belanja sekolah.
\end{abstract}

Kata Kunci: Finansial Pendidikan, Anggaran Pembiayaan, Lembaga Pendidikan

\begin{abstract}
The education budget is often a problem in determining the quality of education, the lack of budget from the government is the main obstacle, with such a small budget, it is certainly necessary to optimize financing. The purpose of this study is to analyze the basic concepts of education financial management and optimizing the education financing budget. This research uses qualitative research methods based on literature study. The data collection method uses documentation studies, namely exploring theories or thoughts from various references. Data analysis uses content analysis, by analyzing and providing data interpretation to draw conclusions. The results of the study explain that. Sources of funds obtained by schools come from the government in the form of central and regional BOS funds, tuition fees for students, and assistance from donors, agencies, sponsors and infaq or sedekah. The available funds are then compiled in the school spending plan which is prepared by the team to be later approved by the principal and the school committee. The implementation of the school financial budget is used in accordance with the budgeted plan in an effective and efficient, trustworthy, and responsible manner. School financial accountability is reported to the directorate of school development (central BOS), the provincial education and culture office, committees, with an accountable and transparent model. The form of optimization can be realized by determining the priority scale when preparing school budgets.
\end{abstract}

Keywords: Education Finance, Financing Budget, Educational Institution 
Hikmah, Vol. 18, No. 1, Januari-Juni 2021, p-ISSN: 1829-8419 e-ISSN: 2720-9040

\section{PENDAHULUAN}

Mewujudkan pendidikan yang berkualitas tentu diperlukan banyak aspek yang saling menunjang. Salah satunya adalah adanya pengelolaan secara menyeluruh dan professional terhadap sumberdaya yang ada dalam sebuah lembaga pendidikan. Sumber daya yang perlu dikelola dengan baik dalam lembaga pendidikan adalah masalah keuangan di sekolah. Pengelolaan keuangan pendidikan merupakan salah satu substansi pengeloaan sekolah yang urgen dalam menentukan berjalannya kegiatan pendidikan di sekolah. (Zietlow et al., 2018)

Keuangan dan pembiayaan merupakan salah satu sumber daya yang secara langsung menunjang efektifitas dan efisiensi pengelolaan pendidikan. Upaya peningkatan mutu disebuah lembaga pendidikan akan sangat bergantung kepada manajemen yang dilaksanakan dalam suatu lembaga pendidikan yang bersangkutan. Manajemen tersebut akan efektif dan efisien apabila didukung oleh sumber daya manusia yang profesional untuk mengoperasikan lembaga pendidikan tersebut. (Masditou, 2017)

Mulai dari kurikulum yang sesuai dengan tingkat perkembangan dan karakteristik siswa, kemampuan dan komitmen tenaga kependidikan yang handal, sarana-prasarana yang memadai untuk mendukung kegiatan belajarmengajar, dana/keuangan yang cukup untuk menggaji pegawai sesuai dengan fungsinya, serta partisipasi masyarakat yang tinggi. Bila salah satu hal di atas tidak sesuai dengan yang diharapkan atau tidak berfungsi sebagaimana mestinya, maka efektivitas dan efisiensi pengelolaan sebuah sekolah Islam tersebut kurang optimal. (Fahmi \& Bitasari, 2021).

Pencapaian tujuan pendidikan kerap terhambat karena minimnya anggaran pendidikan. Walaupun bukan satu-satunya yang menjadi penentu peningkatan kualitas pendidikan, akan tetapi keberadaanya begitu sangat penting. Bahkan-bahkan tanpa adanya pembiayaan tentu bisa saja dikatakan sebuah lembaga pendidikan tidak akan beroperasional. Asupan pembiayaan pendidikan yang tinggi tentu akan semakin meningkatkan banyak program, yang tentunya program itu akan meningkatkan mutu pendidikan.

Namun kondisi saat ini sepertinya tidak menunjukkan yang ideal, saat ini malah anggaran pendidikan sangat minim sehingga kerap membuat para pengelola sekolah harus berpikir sistemik untuk dapat menanggulangi kekurangan tersebut. Banyak cara dilakukan untuk menanggulanginya, mulai dari menaikkan uang iuran sekolah, sampai pada menjalin kerjasama untuk mencari dukungan materi.

Sesuai dengan amanah UUD 1945 bahwa alokasi pendidikan sebesar 20\%, anggaran ini sebenarnya mencakup keluasan yang tanpa batas. Anggaran itu tidak hanya untuk proses yang berkaitan dengan pembelajaran saja, tetapi juga digunakan untuk membayar gaji para pendidik dan tenaga kependidikan.

Untuk mengatasi kekurangan itu tentu sangat diperlukan adanya upaya mengoptimaliasikan anggaran yang ada, hal ini bertujuan agar pemanfaatan dana dapat 
tepat sasaran dan tidak keluar dari yang direncanakan. Optimalisasi tentu saja menggunakan macam cara, namun cara yang paling ideal yang mungkin biasa dilakukan oleh banyak orang adalah skala prioritas. Artinya memprioritaskan hal-hal apa saja yang memang menjadi pilihan untuk dikeluarkan pembiayaanya.

Proses pendidikan dan pembelajaran merupakan kegiatan terencana yang dalam penyusunannya tidak dapat lepas dari faktor pembiayaan. Hal ini karena di dalam pelaksanaannya, ada banyak hal yang harus dilakukan, disiapkan, dan selanjutnya diadakan agar proses pendidikan berlangsung lancar. Berbagai hal yang harus disiapkan dan disediakan oleh pengelola pendidikan, khususnya fasilitas, sarana dan prasarana pendidikan serta kesejahteraan tenaga pengajar/guru. Di sinilah urgennya mengelola keuangan dalam sebuah lembaga pendidikan.

Adapun tujuan penelitian ini yaitu untuk menganalisis konsep dasar manajemen finansial lembaga pendidikan dan optimalisasi anggaran pembiayaan Pendidikan. Penelitian ini memiliki urgensi kepada para pengelola pendidikan khususnya dalam mengoptimalisasikan anggaran pendidikan yang ada, sehingga dapat tepat sasaran, efektif dan efisien.

Untuk melihat novelty dari penelitian ini akan dipaparkan beberapa penelitian yang berkenaan dengan ini, seperti Manajemen finansial pendidikan dengan fokus kajian pada sistem perpajakan (Mesiono \& Lubis, 2021), kemandirian finansial lembaga pendidikan melalui entrepreneurship (Romadhon, 2016), manajemen finansial pondok pesantren (Arifin, 2017), filantropi islam sebagai basis pengelolaan keuangan lembaga pendidikan Islam (Mukhlisin et al., 2019), prinsipprinsip manajemen keuangan pendidikan (Rahmah, 2016), konsep dasar manajemen keungan pendidikan (Komariah, 2018), administrasi keuangan lembaga pendidikan (Napitupulu et al., 2021), manajemen keuangan lembaga pendidikan Islam terpadu (Setiowati, 2015). Berdasarkan beberapa hasil penelitian tersebut tampak bahwa, novelty yang diharapkan dari penelitian ini adalah konsep tentang optimalisasi anggaran pembiayaan pendidikan.

\section{METODE PENELITIAN}

Penelitian ini menggunakan metode penelitian Library Research (studi pustaka). Metode pengumpuland data dilakukan dengan teknik dokumentasi, yakni pengumpulan informasi melalui sumber referensi yang berkaitan dengan topik penelitian. Sumber data yang digunakan dalam penelitian ini adalah legalitas aturan pemerintah tentang finansial pendidikan baik dalam bentuk undang-undang, dan ataupun peraturan pemerintah. Dalam hal ini aturan yang dimaksud ialah Undang-undang No. 20 Tahun 2003 tentang Sistem Pendidikan Nasional dan Perarturan Pemerintah (PP) No 48 tahun 2008 tentang Pendanaan Pendidikan. Sumber pendukung berasal dari buku, jurnal, dan sumber lain yang relevan dengan penelitian ini. Analisis data dilakukan dengan analisis konten yakni analisis terhadap materi yang menjadi rujukan, dan memberikan analisis kritik terhadap materi yang dimaksud. 
Hikmah, Vol. 18, No. 1, Januari-Juni 2021, p-ISSN: 1829-8419 e-ISSN: 2720-9040

Berdasarkan dari berbagai sumber bacaan dan pengalaman penulis tentang topik tersebut, maka penulis mendeskripsikannya menjadi sebuah laporan hasil penelitian.

\section{HASIL DAN PEMBAHASAN}

Sistematisasi pembahasan ini akan disesuaikan dengan tujuan penelitian yang telah dijelaskan pada bagian pendahuluan penelitian ini, yakni konsep dasar manajemen finansial lembaga pendidikan dan upaya optimalisasi anggaran pembiayaan lembaga pendidikan.

\section{Konsep Dasar Manajemen Finansial}

\section{Lembaga Pendidikan}

Manajemen sebagai usaha yang sistematis dalam mengatur dan menggerakkan para anggota atau pegawai yang ada dalam sebuah lembaga, organisasi, agar mereka bekerja dengan kesungguhan dan segenap kemampuan yang dimilikinya. (Gaol, 2020). Sementara Islam kata manajemen didefenisikan jika dinyatakan sebagai pengaturan (al-tadbir), kata ini merupakan derivasi dari kata dabbara (mengatur) yang banyak terdapat dalam AlQur'an seperti firman Allah SWT :

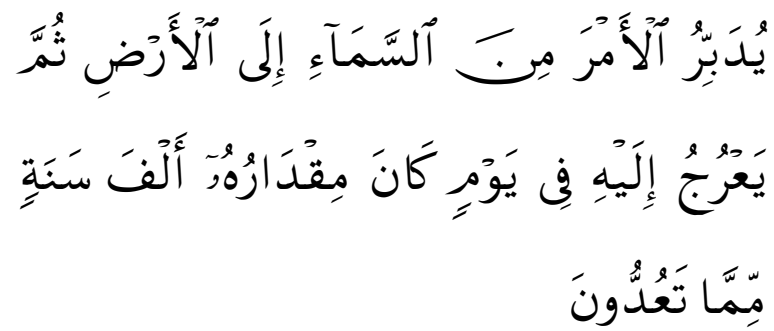

Artinya: Dia mengatur urusan dari langit ke bumi, kemudian (urusan) itu naik kepadanya dalam satu hari yang kadarnya adalah seribu tahun menurut perhitunganmu. (Q. S. as- Sajadah [32]: 5)
Ayat tersebut menjelaskan bahwa Allah adalah maha pengatur seluruh alam semesta dan segala urusan dari langit ke bumi sebelum dan sesudah, dampak atau akibatnya telah diperhitungkan dengan matang sehingga hasilnya sesuai dengan yang dikehendaki. Ayat di atas menjelaskan bahwa Allah SWT, merupakan pengatur alam semesta. Akan tetapi, jika dikaitkan dengan penciptaan manusia yang merupakan khalifah di muka bumi, maka manusia harus mengatur dan mengelola bumi dengan sebaik-baiknya sebagaimana Allah SWT, mengatur alam raya ini. (Hanafiah, 2020).

Sangat jelas pandangan Islam bahwa segala sesuatu harus dilakukan secara rapi, benar, tertib dan teratur. Proses-prosesnya harus diikuti dengan baik, setiap perkara tentu tidak boleh dilakukan secara sembarangan. Inilah merupakan prinsip utama dalam ajaran Islam tentu saja sejalan dengan unsur-unsur manajemen. Berikut ini dapat dilihat mengenai manajemen dan kewajiban untuk bertanggung jawab. Sebagaimana dalam Firman Allah SWT :

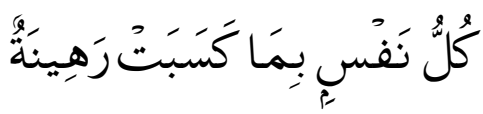

Artinya: tiap-tiap diri bertanggung jawab atas apa yang telah diperbuatnya. (Q S. AlMuddatstsir: [74]: 38)

Jika ayat di atas diintegrasikan dengan konsep manajemen maka dalam hal pengaturan, perkara baik, rapi, tertib, teratur, jujur dan amanah maka itu sesuai dengan konsep dalam Al-Quran. Sebab dalam Islam setiap jiwa akan dimintai pertanggung jawaban terhadap setiap perbuatannya, termasuk dalam hal 
manajemen.

Jika dikaitkan dengan manajemen keuangan pendidikan, pendapat dari Nanang Fatah menyebut dengan pembiayaan pendidikan. Menurut pendapatnya bahwa dalam pembiayaan keperluan penyelenggaraan pendidikan tersebut mencakup berbagai hal. Seperti penggajihan guru, peningkatan professional guru, pengadaan sarana dan prasarana sekolah yaitu ruang belajar yang layak, pengadaan berbagai fasilitas, pengadaan peralatan dan buku pelajaran, alat tulis kantor (ATK), pelaksanaan kegiatan ekstrakurikuler, kegiatan pengelolaan pendidikan dan supervisi pendidikan. (Arwildayanto et al., 2017)

Pemerintah (PP) No 48 tahun 2008 tentang Pendanaan Pendidikan, manajemen keuangan merupakan tindakan pengurusan ketatausahaan dalamhal keuangan yang meliputi pencatatan, perencanaan, pelaksanaan, pertanggungjawaban dan pelaporan masalah keuangan. Pada pendapat lain manajemen keuangan merupakan salah satu substansi manajemen sekolah yang akan menjadi penentu berjalannya kegiatan belajar mengajar di sekolah. (Sari, 2015).

Ringaksnya manajemen keuangan adalah suatu proses melakukan kegiatan mengatur keuangan secara efektif dan efisien dengan menggerakkan tenaga orang lain. Prosesnya di mulai dari penggalian sumber dana, perencanaan, pelaksanaan, sampai pada pelaporan dan pertanggung jawaban keuangan sekolah.

Masalah keuangan dalam lembaga pendidikan yang begitu menentukan kemajuan sekolah harus betul-betul dikelola pihak sekolah. Sebab keuangan dan pendanaan ini turut serta dalam membiayai berbagai keperluan dalam proses pendidikan di sekolah. Keuangan sekolah yang berperan penting dalam penyelenggaraan pendidikan di sekolah. Sebab dengan adanya dana sangat menentukan setiap upaya pencapaian tujuan pendidikan baik tujuan-tujuan yang bersifat kuantitatif maupun kualitatif. (Dwiyama, 2018).

Sumber-sumber pemasukan keuangan sekolah tentu saja dapat diperoleh dari berbagai pihak. Menurut Pasal 46 UU No 20 Tahun 2003 tentang Sistem Pendidikan Nasional, menyatakan bahwa pendanaan pendidikan menjadi tanggung jawab bersama antara pemerintah, pemerintah daerah, dan masyarakat. Jadi, sebagai konsekuensi logisnya maka sumbersumber pemasukan sekolah bisa berasal dari pemerintah pusat dan daerah, usaha mandiri sekolah itu sendiri, dari orang tua siswa, serta masyarakat luas.

Berdasarkan Pemerintah (PP) No 48 tahun 2008 tentang Pendanaan Pendidikan, Jika dijabarkan satu persatu sumber keuangan atau pendanaan sekolah adalah sebagai berikut: bersumber dari pemerintah, berupa Dana Bantuan Operasional Sekolah (BOS), sumber dana pendidikan untuk SD, SMP, dan SMA yang dialokasikan melalui Anggaran Pendapatan dan Belanja Negara (APBN). Selain itu terdapat juga dana khusus yang diperoleh sekolah dari pemerintah daerah provinsi dan kabupaten yang disebut dana khusus dari APBD I dan APBD II. (Barlian, 2016). 
Hikmah, Vol. 18, No. 1, Januari-Juni 2021, p-ISSN: 1829-8419 e-ISSN: 2720-9040

Kemudian yang selanjutnya perolehan sumber dana dari masyarakat, dana ini bisa berasal dari uang SPP siswa atau komite sekolah/orangtua siswa atau dari sponsor dan donatur. Selanjutnya sumber dana dari swadaya beberapa kegiatan yang merupakan usaha mandiri sekolah yang bisa menghasilkan pendapatan sekolah. (Rita \& Santoso, 2017). Usaha mandiri sekolah tersebut diantaranya yaitu: pengelolaan kantin sekolah, pengelolaan koperasi sekolah, pengelolaan internet sekolah, pengelolaan jasa antar jemput siswa, panen kebun sekolah, kegiatan sekolah yang menarik sehingga ada sponsor yang memberi dana, kegiatan seminar/ pelatihan. (Komariah, 2018).

Masih menurut UU Sisdiknas No. 20 tahun 20003, untuk mendapatkan banyak dana sekolah juga bisa mengembangkan penggalian dana dalam bentuk amal jariyah, zakat mal, uang tasyakkuran, amal Jum'at. Bagi sekolah swasta yang biasa minim bantuan pemerintah, maka untuk penggalian sumber pendanaan sekolah harus terus dilakukan dengan berbagai upaya. (Nainggolan, 2012).

Penggalian dana khusus untuk sekolah swasta bisa dilakukan dengan mencari dana dari para donatur berupa sumbangan bantuan sukarela yang sifatnya tak mengikat dan hanya insidental. Atau dalam bentuk bantuan sukarela masyarakat umum yang rutin, dan bantuan sumbangan dari para alumni. Tentang penggalian sumber dana ini, pendapat lain dari Mulyasa, mengatakan bahwa sumber pembiayaan pada sebuah sekolah secara garis besar dapat dikelompokkan kepada tiga sumber, sumber-sumber tersebut antara lain: 1) Pemerintah (pemerintah pusat dan daerah), 2) Orangtua/peserta didik, 3) Masyarakat. (Utama \& Setiyani, 2014).

Berbagai upaya juga dapat dilakukan sekolah dalam penggalian dana seperti, 1) Mengajukan proposal finansial kepada pemerintah pusat maupun daerah, 2) Mengedarkan surat permohonan bantuan kepada orangtua siswa, 3) Mengundang alumni yang sukses untuk dimintai bantuan, 4) Mengadakan kegiatan-kegiatan yang dapat mendatangkan keuntungan finansial bagi sekolah, 5) Mengajukan proposal bantuan finansial kepada kolega, dan donator luar, 6) Memberdayakan wakaf, hibah, infaq, jariyah, dan sebagainya, 7) Memberdayakan solidaritas anggota organisasi keagamaan yang menaungi lembaga pendidikan Islam untuk membantu mencarikan dana. (Mahmud, 2012).

Simpulan dari beberapa pendapat di atas tentang sumber pendaaan, menurut penulis bagi sekolah swasta yang tidak terlalu banyak mendapat dana dari pembiayaan pemerintah. Maka kemandirian sekolah sangat dituntut dalam hal penggalian sumber dana, artinya sekolah harus berusaha agar sekolah tetap bisa berjalan dengan terpenuhinya segala perlengkapan dan pembiayaan sekolah serta proses pembelajaran di sekolah dapat terselenggara hingga mencapai tujuan pendidikan. (Susilo, 2016). Di sinilah sangat diperlukan kerja keras dari manajer keuangan yang dalam hal ini kepala sekolah dalam memikirkan, mencari usaha, atau melobi para donatur untuk memperoleh 
sumber dana. (Handayani \& Prasetyo, 2018).

Selanjutnya terkait dengan Perencanaan dan Pelaksanaan Anggaran Keuangan Lembaga Pendidikan, hal yang perlu untuk diperhatikan adalah menjaga ketertiban pengelolaan keuangan sekolah salah satunya dengan perencanaan yang matang anggaran pembiayaan sekolah dalam kurun waktu tertentu. Sebab ini merupakan proses dasar dimana pengelolaan tersebut harus sesuai dengan rencana, tujuan, dan pelaksanaan yang dicapai. (Farida, 2009).

Bahwa perencanaan harus dilakukan oleh sekolah untuk mensukseskan tujuan yang ingin dicapai sekolah. Pada tahap perencanaan anggaran yaitu penentuan prioritas selama jenjang waktu tertentu, hal ini dilakukan dalam rangka agar pelaksanaan pendidikan berjalan efektif, dan prioritas kebutuhan proses pendidikan. Islam sebagai agama yang sempurna telah menjelaskan bahwa Allah SWT mengisyaratkan pentingnya perencanaan dengan mempertimbangkan kejadiankejadian yang telah lalu untuk merencanakan langkah-langkah ke depan.

Seperti yang terdapat dalam tafsir AlMisbah ayat tersebut menyatakan bahwa kita diperintahkan untuk bertakwa kepada Allah SWT, melaksanakan apa- apa yang diperintahkan Allah dan menjauhi segala yang dilarang oleh Allah SWT, dan hendaklah seseorang melihat apa yang telah diperbuatnya untuk hari esok (hari kiamat), dan selalu melakukan introspeksi dan perbaikan guna mencapai masa depan yang lebih baik.
Pendapat yang serupa dari Muchdarsyah Sinungan yang menekankan harus ada pada penyusunan rencana (planning) di dalam setiap penggunaan anggaran. Menurutnya, langkah yang perlu dilakukan dalam merencanakan pembiayaan yaitu menganalisa berbagai aspek yang berhubungan erat dengan anggaran, yang didasarkan pertimbangan kondisi keuangan, line of business, keadaan para nasabah/konsumen, organisasi pengelola, dan skill para pejabat pengelola.

Sementara itu menurut Morphet sebagaimana dikutip oleh Mulyasa menjelaskan tentang hal-hal yang perlu diperhatikan dalam penganggaran biaya pendidikan yaitu: 1) Anggaran belanja sekolah harus sesuai dengan peraturan dan prosedur agar dana efektif digunakan sesuai dengan kebutuhan pendidikan, 2) Harus merencanakan anggaran yang relevan, sehingga efektif, 3) Melakukan monitor secara terus menerus dan berkesinambungan sebagai bahan perencanaan tahap berikutnya.

Pendapat yang menguatkan agar sistem pengelolaan keuangan di sekolah berjalan baik, maka perlu mengefektifkan pembuatan perencanaan keuangan sekolah, dan yang sangat bertanggung jawab sebagai pelaksana ini tentunya adalah kepala sekolah. Kepala sekolah memiliki peran sentral dimana dia harus mampu mengembangkan sejumlah dimensi pengembangan administrativ yang ada di sekolah. Penyusunan rencana anggaran tersebut memerlukan analisis masa lalu dan lingkungan ekstern yang mencakup kekuatan (strength), kelemahan (weakness), 
Hikmah, Vol. 18, No. 1, Januari-Juni 2021, p-ISSN: 1829-8419 e-ISSN: 2720-9040

peluang (opportunities) dan ancaman (threats).

Guna mendukung terciptanya pengelolaan keuangan yang efesien, maka dalam perencanaan anggaran bagi sekolah Islam harus memperhatikan hal berikut: Pertama harus hemat dan sesuai dengan kebutuhan sekolah, tak mubajir. Kedua, terarah dan terkendali sesuai dengan rencana, artinya tak menggunakan dana tidak pada tempatnya. Ketiga, tidak boleh dalam perencanaan ada dana yang diperuntukan pada kebutuhan yang tidak perlu dan tak menunjang proses belajar mengajar, seperti kartu ucapan selamat, hadiah, dan pesta.

Berdasarkan pendapat-pendapat para ahli tersebut di atas maka dapat penulis simpulkan bahwasannya untuk mencapai tujuan dalam manajemen keuangan di lembaga pendidikan/yayasan, sangat diperlukan pengaturan dalam hal perencanaan anggaran dan juga dalam melaksanakan apa saja yang sudah di rencanakan. Diperlukan transparansi, akuntabilitas, efektivitas, dan efisiensi dalam pengelolaan keuangan sekolah. Hal itu kiranya dalam pelaksanaan manajemen keuangan pada lembaga pendidikan Islam dapat berjalan efektif dan tepat sasaran. Sehingga mengurangi kemungkinan akan terjadi pemakaian dana yang tidak efektif atau mubazir.

Manajemen keuangan sekolah perlu memperhatikan sejumlah prinsip-prinsip yang akan menjadi acuan dan pedoman dalam pengelolaan keuangan sekolah. Menurut Undang-undang No 20 Tahun 2003 pasal 48 menyatakan bahwa pengelolaan dana pendidikan berdasarkan pada prinsip keadilan, efisiensi, transparansi, dan akuntabilitas publik, prinsip efektivitas juga perlu mendapat penekanan.

Lebih jelasnya tentang prinsip manajemen keuangan sekolah tersebut, yaitu transparansi, akuntabilitas, efektivitas, dan efisiensi akan dibahas satu persatu :

1. Transparansi, artinya harus ada keterbukaan. Transparan di bidang manajemen keuangan berarti adanya keterbukaan dalam mengelola keuangan di sekolah, jelas dan rinci pengeluarannya.

2. Akuntabilitas, akuntabilitas di dalam manajemen keuangan berarti penggunaan uang sekolah dapat dipertanggungjawabkan sesuai dengan perencanaan yang telah ditetapkan.

3. Efektivitas, sebagai pencapaian tujuan yang telah ditetapkan dalam anggaran. Efektivitas tidak berhenti sampai tujuan tercapai tetapi sampai pada kualitatif hasil yang dikaitkan dengan pencapaian visi lembaga.

4. Efisiensi, Hal ini berkaitan dengan kuantitas hasil suatu kegiatan. Efisiensi dalam manajemen keuangan berarti adanya hasil yang terbaik antara masukan (input) dan pengeluaran (out put). Efesien di sini juga meliputi tenaga, pikiran, waktu, dan biaya dan penyelenggaraan pendidikan. (Hanifah \& Praptoyo, 2015).

Aspek yang tak kalah urgen yaitu dalam masalah pelaporan dan pertanggung 
jawaban manajemen keuangan sekolah. Perlu ada evaluasi dalam keberhasilan pelaksanaan program sekolah dengan kriteria tertentu untuk keperluan pembuatan keputusan berikutnya. Pertanggungjawaban dan pelaporan mengenai pendanaan keuangan sekolah menyangkut seluruh pengeluaran dana untuk pembiayaan di sekolah. Apa yang telah dicapai harus sesuai dengan tujuan yang telah ditetapkan. Proses pertanggungjawaban dan pelaporan dana keuangan baik pemasukan, penyimpanan, dan pengeluaran dana diserahkan kepada pihak-pihak yang berhak untuk mengetahuinya. (Nuryeti, 2018).

Pendapat lain juga mengatakan hal yang sama, akuntabilitasi pengelolaan keuangan suatu lembaga pendidikan harus dipertanggungjawabkan dalam pelaporan. Artinya pengelolaan keuangannya harus dipertanggungjawabkan seakuntabel mungkin kepada pihak yang berhak mengetahuinya. Dalam implementasinya pertanggungjawaban dalam manajemen sekolah dilakukan setiap akhir tahun anggaran. Pertanggung jawaban tersebut menjadi bentuk dari transparansi pengelolaan keuangan. (Feriansyah \& Harnawansyah, 2021).

Kaitannya dengan pengelolaan keuangan sekolah, yang perlu diperhatikan oleh pihak yang diserahkan oleh pihak sekolah yaitu kepada bendaharawan lembaga pendidikan, adalah sebagai berikut: 1) pada setiap akhir tahun anggaran, bendaharawan wajib membuat laporan pertanggungjawabkan keuangan yang akan dilaporkan ke pihak yang berhak. 2) laporan keuangan tersebut harus dilampiri bukti- bukti kuitansi pemasukan dan pengeluaran yang ada, termasuk bukti penyetoran pajak (PPN \& PPh) bila ada. 3) bendahara harus melampirkan bukti kwitansi atau bukti-bukti pembelian atau bukti penerimaan berupa tanda tangan, penerimaan honorarium/bantuan atau bukti pengeluaran lainya yang dianggap sah. 4) bendaharawan bertugas dalam melaporkan neraca keuangan yang harus ditunjukkan untuk diperiksa dalam pelaporan. (Weikart et al., 2012).

Maka dari beberapa pendapat di atas dapat diketahui bahwasannya pertanggung jawaban dalam hal keuangan di lembaga pendidikan adalah proses pembuktian dan penentuan bahwa apa yang dilaksanakan sesuai dengan apa yang direncanakan, hal ini meliputi pertanggungjawaban penerimaan dana, penyimpanan dan pengeluaran dana sesuai dengan perencanaan (proporsional). Pertanggungjawaban tersebut dilaporkan baik pada masyarakat dalam hal ini orang tua Siswa, komite, penyandang dana atau para donatur dan pemerintah.

\section{Optimalisasi Anggaran Pembiayaan Lembaga Pendidikan}

Minimnya anggaran pembiayaan untuk lembaga pendidikan, bukan lantas berarti pembelajaran tidak terlaksana, namun dalam kondisi itu pengelola pendidikan harus mampu untuk mengoptimalisasikan dana yang ada. Tidak semua rencana belanja harus di tunaikan, ada beberapa dari rencana belanja yang memang dapat di batalkan atau ditunda pengadaanya, hal tersebut bertujuan untuk 
Hikmah, Vol. 18, No. 1, Januari-Juni 2021, p-ISSN: 1829-8419 e-ISSN: 2720-9040

dapat mengoptimalisasikan pembiayaan.

Terkait dengan optimaliasi maka ada beberapa bentuk optimalisasi anggaran pembiayaan, dan perlu untuk ditegaskan bahwa beberapa bentuk optimalisasi ini merupakan novelty penelitian sebagaimana yang telah diharapkan sebelumnya:

1. Optimalisasi melalui skala prioritas, tim perumus anggaran harus memetakan beberapa item yang menjadi prioritas untuk dapat realisasi anggaran yang ada. Skala prioritas dapat didasarkan pada kebutuhan, atau juga didasarkan pada aturan yang ada.

2. Optimalisasi melalui pengurangan kuantitas. Kadang kala tidak harus terpenuhi semuanya, sebab kekurangan dana akhirnya memaksa bahwa kuantitas harus disesuaikan dengan alokasi biaya yang ada. Dalam arti jumlah yang ada disesuaikan dengan anggaran yang ada.

3. Optimalisasi anggaran melalui pemanfaatan anggaran secara efektif dan eisien. Pemanfaatan tersebut dapat meminimalisasinya terjadi kesalahan atau penyelewengan dana, sehingga pencapaian tujuan tepat sasaran.

4. Optimalisasi melalui tambahan dana, sumber dana dari pemerintah sangat memungkinkan untuk mendapatkan asupan tambahan dana dari donatur, atau sumbangan yang sifatnya tidak mengikat, Sumbangan terebut tentu saja menjadi langkah optimalisasi.
5. Optimalisasi melalui analisis SWOT analisi ini bertujuan untuk meminimalisasi terjadinya kesalahan penerapan, sebab semakin tinggi kesalahan ataupun kegagalan maka akan semakin tinggi pula kemungkinan kegagalan yang didapat.

\section{SIMPULAN}

Berdasarkan penjelasan di atas maka dapat ditarik simpulan bahwa harus jelas penggalian sumber dana yang dilakukan sekolah dalam hal ini oleh kepala sekolah sudah berjalan, sumber dana dari pemerintah baik pusat maupun daerah dikelola dengan transfaran, efektif dan efisien, dana dari masyarakat dalam hal ini orang tua berupa iuran SPP setiap bulan, juga harus dikelola dengan transfaran, efektif dan efisien. Kemudian terkait dengan perencanaan perencanaan anggaran harus dibuat oleh tim dan terealisasi sesuai rencana, dan pelaksanaan dalam hal ini pembukuan masuk dan keluarnya uang tercatat dan terlihat dengan pembiayaan sekolah baik biaya rutin maupun biaya operasional sekolah harus tercukupi dan terpenuhi. Selanjutnya berkaitan dengan pelaporan atau pertanggung jawaban keuangan untuk dana yang bersumber dari pemerintah laporannya sesuai prosedur dan dapat dipertanggungjawabkan ke pihak yang berwenang yaitu pemerintah pusat dan daerah. Sedangkan pelaporan dana dari orang tua siswa berupa iuran SPP yang dilaporkan setiap tahunnya ke ketua komite.. Staf pegawai atau orang-orang yang menjalankan manajemen keuangan di 
Hikmah, Vol. 18, No. 1, Januari-Juni 2021, p-ISSN: 1829-8419 e-ISSN: 2720-9040

lembaga pendidikan Islam ini adalah orang yang amanah dan bertanggung jawab, maka tidak akan mungkin melakukan tindakan korupsi, manipulasi penyalahgunaan dana dan lainnya. Manajemen keuangan sekolah jika benar-benar di kelola oleh orang-orang yang memiliki kompetensi yaitu keterampilan dan kemampuan untuk menjalankan ilmu akuntansi, teknologi informasi yang modern dan jika dipadukan dengan manajemen yang Islami dengan orang-orang yang memiliki soft skiil yang baik maka akan menghasilkan produk yang baik. Adapun bentuk optimaliasi anggaran pembiayaan lembaga pendidikan yaitu optimalisasi melalui skala prioritas, optimalisasi melalui pengurangan kuantitas, optimalisasi anggaran melalui pemanfaatan anggaran secara efektif dan eisien, optimalisasi melalui tambahan dana, dan optimalisasi melalui analisis SWOT

\section{DAFTAR PUSTAKA}

Arifin, M. (2017). Manajemen Keuangan Pondok Pesantren. Fikrotuna, 4(2). https://doi.org/10.32806/jf.v4i2.2745

Arwildayanto, A., Nina, L., \& Warni, T. S. (2017). Manajemen Keuangan dan pembiayaan pendidikan. Widya Padjadjaran.

Barlian, U. C. (2016). Kebijakan Pengelolaan Dana Pendidikan Tingkat Sekolah dalam Konteks Otonomi Daerah. An-Nidzam: Jurnal Manajemen Pendidikan Dan Studi Islam, 3(2), 69-86. http://jurnal.upi.edu/manajerial/view/2 681/Kebijakan Pengelolaan Dana Pendidikan Tingkat Sekolah dalam Konteks Otonomi Daerah

Dwiyama, F. (2018). Unsur Manajemen dalam Pengelolaan Lembaga
Pendidikan Islam di Indonesia. Adaara: Jurnal Manajemen Pendidikan Islam, 7(1), 675-695.

Fahmi, F., \& Bitasari, W. (2021). Revitalisasi Implementasi Kurikulum Pendidikan. Al-Fikru: Jurnal Ilmiah, 14(2), 81-91. https://doi.org/10.51672/alfikru.v14i2.3 0

Farida, S. (2009). Manajemen Keuangan Sekolah di SMA Muhammadiyah 1 Simo Tahun Ajaran 2008/2009. Universitas Muhammadiyah Surakarta.

Feriansyah, F., \& Harnawansyah, M. F. (2021). Evaluasi Administrasi Program Bantuan Operasional Sekolah Studi Kasus: SD Negeri 9 Kikim. Jurnal Pasira, 3(5), 1-13. http://ojs.fisipunmura.com/index.php/pasira/article/vi ew/6

Gaol, N. T. L. (2020). Sejarah dan konsep manajemen pendidikan. Jurnal Dinamika Pendidikan, 13(1), 79-88. https://doi.org/10.51212/jdp.v13i1.137 3

Hanafiah, M. A. (2020). Peran Kepala Sekolah/Madrasah dalam Menjaga Mutu Pendidikan Pada Masa Tersebarnya Virus Corona (Covid-19). Al-Fikru: Jurnal Ilmiah, 13(2), 119123.

http://jurnal.staiserdanglubukpakam.ac. id/index.php/alfikru/article/view/15

Handayani, R., \& Prasetyo, A. E. (2018). Implementasi Sistem Informasi Keuangan Pada Sekolah Swasta di Kabupaten Lamongan Guna Mewujudkan Transparasi dan Pelayanan Prima Kepada Masyarakat. Community Development Journal, 2(2), 367-372.

Hanifah, S. I., \& Praptoyo, S. (2015). Akuntabilitas dan Transparansi Pertanggungjawaban Anggaran Pendapatan Belanja Desa (APBDes). Jurnal Ilmu Dan Riset Akuntansi 
Hikmah, Vol. 18, No. 1, Januari-Juni 2021, p-ISSN: 1829-8419 e-ISSN: 2720-9040

(JIRA), 4(8), 30-56. http://jurnalmahasiswa.stiesia.ac.id/ind ex.php/jira/article/view/3584

Komariah, N. (2018). Konsep Manajemen Keuangan Pendidikan. Al-Afkar: Jurnal Keislaman \& Peradaban, 6(1), 67-94.

https://doi.org/10.32520/afkar.v6i1.192

Mahmud, M. E. (2012). Motif Penyelenggaraan Pendidikan Islam dan Implikasinya pada Pola Manajemen dan Kepemimpinan. Dinamika Ilmu: Jurnal Pendidikan, 12(2), 50-78. https://doi.org/10.21093/di.v12i2.60

Masditou. (2017). Manajemen Pembiayaan Pendidikan Menuju Pendidikan Yang Bermutu. Jurnal Ansiru PAI.

Mesiono, M., \& Lubis, R. R. (2021). Manajemen Finansial Pendidikan di Indonesia (Diskursus Sistem Perpajakan pada Institusi Pendidikan). Al-Fikru: Jurnal Ilmiah, 15(1), 14-27. https://doi.org/10.51672/alfikru.v15i1.2 1

Mukhlisin, M., Mujahidin, E., \& Indupurnahayu, I. (2019). Filantropi Islam sebagai Strategi Manajemen Keuangan Lembaga Pendidikan. Idarah Tarbawiyah: Journal of Management in Islamic Education, 1(1), 27-36. http://dx.doi.org/10.32832/itjmie.v1i1. 2702

Nainggolan, P. (2012). Manajemen keuangan lembaga nirlaba. Yayasan Bina Integrasi Edukasi.

Napitupulu, D. S., Zamil, A., \& Alfiyah, S. (2021). Administrasi Keuangan Lembaga Pendidikan Islam. mudabbir (Journal Research and Education studies), $\quad 1(1), \quad 12-20$. http://jurnal.permapendissumut.org/index.php/mudabbir/article/ view/2

Nuryeti, Y. (2018). Pengaruh Implementasi
Kebijakan terhadap Manajemen Rencana Kerja dan Anggaran Sekolah dalam Mewujudkan Efektivitas Laporan Pertanggungjawaban Penggunaan Anggaran Keuangan Madrasah. Khazanah Akademia, 2(1), 94-104. https://journal.uniga.ac.id/index.php/K/ article/view/335

Rahmah, N. (2016). Prinsip-Prinsip Manajemen Keuangan Sekolah. Kelola: Journal of Islamic Education Management, 1(1), 73-77. https://doi.org/10.24256/kelola.v1i1.43 0

Rita, M. R., \& Santoso, B. (2017). Literasi Keuangan Dan Perencanaan Keuangan Pada Dana Pendidikan Anak. Jurnal Ekonomi, 20(2), 212-227. https://ecojoin.org/index.php/EJE/articl e/view/157

Romadhon, A. (2016). Kemandirian Finansial Lembaga Pendidikan Melalui Entrepreneurship dan Partnership. Jurnal Manajemen Pendidikan, 7(1), 1197-1204. https://doi.org/10.21009/jmp.07101

Sari, Y. (2015). Manajemen keuangan di Lembaga Pendidikan Anak Usia Dini EFAC Desa Kalipucung Kecamatan Sanankulon Kabupaten Blitar. Universitas Negeri Malang. http://repository.um.ac.id/3622/

Setiowati, N. E. (2015). Manajemea Pembiayaan Pendidikan Pondok Pesantren dan Lembaga Pendidikan Terpadu Nurushiddiiq Cirebon [Sykeh Nurjati Cirebon]. http://repository.syekhnurjati.ac.id/469 3/1/Nilai Reviewer_Jurnal 3.pdf

Susilo, M. J. (2016). Kajian kemandirian sekolah di amal usaha muhammadiyah. Prosiding Seminar Nasional Pendidikan Berkemanjuan Dan Menggembirakan, 625-633.

Utama, D. A., \& Setiyani, R. (2014). 
Pengaruh Transparansi, Akuntabilitas, dan Responsibilitas Pengelolaan Keuangan Sekolah Terhadap Kinerja Guru. Dinamika Pendidikan, 9(2). https://doi.org/10.15294/dp.v9i2.4886

Weikart, L. A., Chen, G. G., \& Sermier, E. (2012). Budgeting and financial management for nonprofit organizations. CQ Press.

Zietlow, J., Hankin, J. A., Seidner, A., \& O'Brien, T. (2018). Financial management for nonprofit organizations: policies and practices (Second Edi). John Wiley \& Sons. 